November - 2007

\title{
Identifying Effective Pedagogical Approaches for Online Workplace Training: A case study of the South African wood products manufacturing sector
}

\author{
Ian S. Macdonald \\ University of British Columbia, Canada \\ Mark Bullen \\ British Columbia Institute of Technology, Canada \\ R. A. Kozak \\ University of British Columbia, Canada
}

\begin{abstract}
This study investigated appropriate pedagogical techniques for workplace e-learning programs in the South African wood products (furniture) manufacturing sector. The study found that learners responded favourably to constructivist teaching approaches, such as asynchronous discussions, open-ended task-based activities, and assignments incorporating authentic, real-world examples. Learners viewed constructivist activities to be more useful than quizzes and traditional essaybased assignments, as they allowed new concepts to be learned in context and were perceived to promote deeper understanding of the subject matter. Nevertheless, they valued the inclusion of a blend of pedagogical approaches in the course design, as this enabled them to approach and analyze new concepts in an assortment of ways. Learners placed importance on regular interaction with other learners and course instructors, and were strongly in favour of including face-to-face components in Web-based courses.
\end{abstract}

Keywords : e-learning; pedagogy; constructivism; workplace learners; corporate training; learning activities

\section{Introduction}

South Africa has one of the best-developed economies and highest standards of living in Africa, and its Internet infrastructure - although poor compared to western industrialised nations - is well-established in African terms (World Bank, 2000). Despite these advantages, it shares many of the challenges that its economically less-fortunate neighbours experience. These include extreme poverty among a large percentage of the population and an unemployment rate that has recently been estimated at 41.2 per cent $^{1}$ (Streak \& van der Westhuizen, 2004). Given the availability of environmentally-certified plantation forest resources, the forest products industry in South Africa offers a potential opportunity to address poverty and unemployment by increasing the domestic production of wood products such as furniture. A major barrier to achieving such 
Identifying Effective Pedagogical Approaches for Online Workplace Training:

A case study of the South African wood products manufacturing sector

Macdonald, Bullen, \& Kozak

growth, however, is a lack of appropriate skills; South Africa's Forest Industry Education and Training Authority states that "78 per cent of the forest industry workforce is either semi- or unskilled, and there are critical shortages of craft or skilled workers, technicians, and professional managers" (FIETA, 2006). New post-secondary and tertiary education programs are being developed in response to this problem, and e-learning is being considered as a delivery mode for industry training programs because it allows for flexible study schedules and eliminates the need for employees to leave the workplace and incur costly travel expenses. Two pilot e-learning courses on forestry for undergraduate learners have been offered by the University of Stellenbosch, South Africa, and students responded favourably to the e-learning format (Längin, Lewark, \& Ackerman, 2004). The results suggest that e-learning may also be an appropriate format for corporate workplace training, which has prompted the present study.

Using a qualitative approach, this research project investigated various pedagogical approaches in order to determine the most appropriate ways of conducting online workplace training in the South African wooden furniture sector. More specifically, it explored whether constructivist teaching and learning was an effective approach. The principal research question of the study was "Is constructivist teaching and learning an effective pedagogical approach for use in Webbased training for adult workplace learners in South Africa?” In addition, a number of secondary questions relating to corporate support for workplace e-learning, adequacy of computer infrastructure in South Africa, and computer literacy requirements were posed, though these are not discussed in this article.

Adult learners are likely to be relatively unfamiliar with constructivist methods of instruction instead, they can be expected to be much more familiar with didactic teaching approaches which are prevalent in traditional school and university environments (Akerlind \& Trevin, 1995). However, if the rationale for the constructivist approach is clearly explained, and learners are given sufficient opportunity to become comfortable with this style of instruction, it is believed that the approach can be both meaningful and effective.

\section{Research Methods}

A qualitative case study approach was selected for this study in order to obtain detailed information in a flexible, semi-structured interview format, and to allow for complex interactional variables that typically occur in learning environments to be taken into account (Cronbach, 1975). A quantitative study of learners enrolled in several courses was deemed inappropriate because it would not allow the researcher to frame problems as open-ended questions (Patton, 1990) or to probe issues which had not been anticipated during the questionnaire design process. Furthermore, the teaching and learning methods employed in the various courses would not be uniform and it would be impossible, in practical terms, to ensure that consistent approaches were being used across all courses. It was decided to adapt a specific e-learning course as the focus of the study so that the researcher was able to control and manipulate all of the key variables related to course design, including the course content, types of learning activities used, presentation of content, assessment criteria, student workload, and the timing of the course. In doing so, the researcher was able to ensure that a diverse range of teaching and learning activities were present for participants to experience and comment upon, so that the project would be as informative as possible.

The course selected for use as the research vehicle was an online, first-year undergraduate course, developed at the Faculty of Forestry, University of British Columbia. This course was intended to introduce students to what is known as the forest products value chain, beginning with the 
Identifying Effective Pedagogical Approaches for Online Workplace Training:

A case study of the South African wood products manufacturing sector

Macdonald, Bullen, \& Kozak

planting and management of forests, introducing the taxonomy of wood products, and then subsequently discussing all of the key manufacturing stages through to the global trade in forest products and the various issues and interrelationships along the supply chain. The course is delivered using the WebCT course management system.

A group of 20 South African workplace learners were selected to participate in the course, which was 14 weeks in duration. This sample size was chosen as it was manageable enough to allow for detailed, one-on-one interviews with each participant to be conducted before and after the course, yet still yielded a varied range of opinions and experiences. During the course, WebCT server logs, quiz scores, and grades for other assessed activities were monitored by the researcher ${ }^{2}$. Candidates for the study were identified with the help of regional human resources managers. Participants were required to have computer experience and to be working in occupations that were relevant to the subject matter of the course being offered. While human resources managers disseminated information about the course to suitable candidates, participation was voluntary. Consent forms were obtained from all of the participants, and the study was reviewed and approved by The University of British Columbia's Ethics Board.

\section{Adaptation of the E-learning Course}

To prepare for the study, the course content was substantially adapted and augmented so that it was germane to South African participants. In addition, a pedagogical redesign was undertaken with the aim of providing as wide a variety of teaching and learning activities as possible within the same course, while still maintaining a learning environment in which learners could progress comfortably. This involved changing the order of course modules, as some types of content lent themselves more readily to a particular pedagogical approach. It was decided that creating five discrete modules, each based upon a different learning theory and with no common elements, would confuse learners, and consequently, render the study of little use as a framework for evaluating appropriate pedagogies. For this reason, a more gradual, phased tactic was employed, in which a behaviourist approach in the first part of the course led toward a more constructivist, learner-centred approach in the latter half. The behaviourist approach was chosen for the early part of the course because this is the teaching style that is predominantly and traditionally employed in classroom instruction in schools and higher education. It was anticipated that familiarity with this style of instruction would build learner confidence in the early stages of the course. Module-by-module, learning activities were designed to progress smoothly toward a more constructivist approach, with more loosely defined tasks and greater freedom for the students to play a more direct role in their own learning. A constructivist approach - the focus of one of the key research questions of this study - was used in the later modules. Cognitivist principles guided the creation of optional self-test exercises used at various points in the course.

Table 1 describes the pedagogical approaches and learning activities employed in the course. The course did not represent a perfectly linear progression from a behavioural to a constructivist approach, since course content often lends itself to one pedagogical approach more so than another (Tennyson, 2002). A series of short quizzes were created within the WebCT electronic quiz tool, and these were integrated into the first two modules of the course, which were contentdriven and involved highly-structured learning activities testing declarative and procedural knowledge. Online discussion questions were posed in Modules 4 and 5, and were designed to encourage learners to relate personal experiences and perspectives to the course content as a means of developing knowledge in context. Each module contained a major assignment - in the early modules, these focused on testing comprehension of information supplied in the online course text, while later modules promoted independent research and the social exchange of ideas 
Identifying Effective Pedagogical Approaches for Online Workplace Training: A case study of the South African wood products manufacturing sector

Macdonald, Bullen, \& Kozak

to achieve authentic project-based tasks. Modules 1 and 3 also contained short optional exercises within the online text pages that encouraged learners to augment the information presented in the online text pages with their own relevant experiences.

Table 1. Pedagogical Approaches and Learning Activities employed in the Course

\begin{tabular}{|c|c|c|}
\hline Module & Pedagogical Approach & Learning Activities \\
\hline $\begin{array}{l}\text { 1. Forest } \\
\text { Management } \\
\text { Issues and } \\
\text { Practices }\end{array}$ & $\begin{array}{l}\text { Followed a behavioural/ } \\
\text { transmissive approach that } \\
\text { promoted leaming in small, } \\
\text { controlled steps and relied } \\
\text { on a designated source of } \\
\text { content information (course } \\
\text { website, supporting PDF } \\
\text { documents). Emphasis on } \\
\text { acquisition of declarative } \\
\text { and procedural, rather than } \\
\text { contextual, knowledge. } \\
\text { Assessed activities measured } \\
\text { intermalisation of predefined } \\
\text { set of facts (those supplied } \\
\text { in course website). } \\
\text { Cognitivist principles, in } \\
\text { which new information is } \\
\text { related to prior knowledge } \\
\text { and experience, guided the } \\
\text { creation of optional } \\
\text { exercises provided within } \\
\text { the text. }\end{array}$ & $\begin{array}{l}\text { Short quizzes consisting } \\
\text { predominantly of multiple-choice } \\
\text { questions to test recall of declarative } \\
\text { knowledge (assessed). Exercises } \\
\text { relating personal experience and } \\
\text { opinions to course content (optional, } \\
\text { unassessed). } \\
\text { Assignment 1-review and } \\
\text { summarise values, issues, and } \\
\text { conflicts related to forestry in South } \\
\text { Africa based upon reading a } \\
\text { government website and White } \\
\text { Paper (assessed). }\end{array}$ \\
\hline $\begin{array}{l}\text { 2. Taxonomy of } \\
\text { Wood Products }\end{array}$ & $\begin{array}{l}\text { Followed the behavioural } \\
\text { approach described above. }\end{array}$ & $\begin{array}{l}\text { Short quizzes consisting } \\
\text { predominantly of multiple-choice } \\
\text { questions to test recall of declarative } \\
\text { knowledge (assessed). } \\
\text { Assignment } 2 \text { - provide point-form } \\
\text { answers to a list of questions based } \\
\text { directly upon online course text } \\
\text { (assessed). }\end{array}$ \\
\hline
\end{tabular}


Identifying Effective Pedagogical Approaches for Online Workplace Training: A case study of the South African wood products manufacturing sector

Macdonald, Bullen, \& Kozak

\begin{tabular}{|c|c|c|}
\hline $\begin{array}{l}\text { 3. Primary } \\
\text { Processing of } \\
\text { Wood Products }\end{array}$ & $\begin{array}{l}\text { Transition point between } \\
\text { primarily behaviourist } \\
\text { approach of first two } \\
\text { modules and more } \\
\text { constructivist approach of } \\
\text { Modules } 4 \text { and } 5 \text {. Assessed } \\
\text { quizzes no longer included, } \\
\text { but sets of self-test questions } \\
\text { provided as means of } \\
\text { flagging core concepts that } \\
\text { learners were required to } \\
\text { leam. Assignment tested } \\
\text { leamers' ability to link } \\
\text { concepts introduced in } \\
\text { online text to real-world } \\
\text { contexts, setting the scene } \\
\text { for more flexible and } \\
\text { authentic learning tasks in } \\
\text { later modules. }\end{array}$ & $\begin{array}{l}\text { Self-test questions at end of each } \\
\text { section of content allow learners to } \\
\text { verify whether they can recall key } \\
\text { facts and concepts (unassessed). } \\
\text { Assignment } 3 \text { - describe all of the } \\
\text { main stages in the manufacture of } \\
\text { solid lumber, starting with the } \\
\text { felling of the tree (from online text). } \\
\text { Suggest ways that occurrences at } \\
\text { each stage in the process could } \\
\text { affect the quality of the final product } \\
\text { or of a downstream value-added } \\
\text { product. }\end{array}$ \\
\hline $\begin{array}{l}\text { 4. Secondary } \\
\text { Processing of } \\
\text { Wood Products }\end{array}$ & $\begin{array}{l}\text { Employed a constructivist } \\
\text { approach, still with some } \\
\text { direct instruction (HTML } \\
\text { pages of course content), but } \\
\text { with encouragement and } \\
\text { opportunity for leamers to } \\
\text { go beyond the information } \\
\text { given. Greater emphasis and } \\
\text { validity given to individual } \\
\text { opinions and experience and } \\
\text { third-party online } \\
\text { information sources, versus } \\
\text { the dominance of "official' } \\
\text { facts provided in the online } \\
\text { course text. Social } \\
\text { interaction and exchange of } \\
\text { information with peers } \\
\text { facilitated via the discussion } \\
\text { forum. }\end{array}$ & $\begin{array}{l}\text { Discussion questions asked learners } \\
\text { to: } 1 \text {. provide opinions on the } \\
\text { meaning of the term "value-added } \\
\text { product" using examples from own } \\
\text { industry, and; } 2 \text {. weigh the economic } \\
\text { versus social impacts of factory } \\
\text { automation in South Africa. } \\
\text { Assignment } 4 \text {-leamers asked to } \\
\text { conduct independent research that } \\
\text { considered authentic variables in the } \\
\text { furniture manufacturing process, } \\
\text { using suggested Web links and } \\
\text { reputable websites of their choice as } \\
\text { sources of information. }\end{array}$ \\
\hline
\end{tabular}


Identifying Effective Pedagogical Approaches for Online Workplace Training: A case study of the South African wood products manufacturing sector

Macdonald, Bullen, \& Kozak

\begin{tabular}{|c|c|c|}
\hline $\begin{array}{l}\text { 5. Global Trade } \\
\text { in Forest } \\
\text { Products }\end{array}$ & $\begin{array}{l}\text { Employed a social } \\
\text { constructivist approach, } \\
\text { incorporating authentic, } \\
\text { project-based activities and } \\
\text { collaborative leaming, but } \\
\text { based upon well-structured } \\
\text { content and objectives. } \\
\text { Learners given even greater } \\
\text { flexibility in shaping their } \\
\text { own leaming, and } \\
\text { authenticity was } \\
\text { emphasised. Discussion } \\
\text { forum questions allowed } \\
\text { learners to share opinions } \\
\text { and leam from differing } \\
\text { experiences and perspectives } \\
\text { of their peers. Final } \\
\text { assignment was team-based } \\
\text { activity resembling a task } \\
\text { that managers may be asked } \\
\text { to do in the workplace, and } \\
\text { encouraging practical } \\
\text { application of knowledge } \\
\text { gained during the course } \\
\text { within a real-world context. } \\
\text { Chat tools and discussion } \\
\text { forums provided as a means } \\
\text { for groups to communicate } \\
\text { and collaborate. }\end{array}$ & $\begin{array}{l}\text { Discussion questions asked leamers } \\
\text { to: } 1 \text {. exchange opinions on Africa's } \\
\text { future role in global forest products } \\
\text { trade, and; } 2 \text {. comment on a market } \\
\text { analysis report on the South African } \\
\text { furniture sector. } \\
\text { Assignment } 5 \text {-in pre-assigned } \\
\text { groups of three, leamers asked to put } \\
\text { themselves in the role of } \\
\text { entrepreneurs developing a new } \\
\text { business venture. Leamers were } \\
\text { tasked with creating a mini product } \\
\text { development plan, incorporating } \\
\text { knowledge gained throughout the } \\
\text { course. }\end{array}$ \\
\hline
\end{tabular}

\section{Technological Considerations}

In choosing how information should be presented in the course, it was decided not to rely upon media or applications that required high bandwidth (video, animated simulations, audio) as it was foreseen that this would cause accessibility problems for some learners due to slow modem connections and poor bandwidth. Presentation of content was achieved through text-based HTML pages supported by photos, diagrams, and charts. Supplementary resources, such as third-party reports, were converted to the Adobe PDF document format and optimized such that the file size was as small as possible before posting them on the course website.

\section{Selection of Study Participants}

In selecting a group of learners to participate in the study, it was deemed important to minimize variation with respect to access to technology and corporate policies towards training. For this reason, all of the learners were selected from one large, diversified company. The company chosen was Steinhoff Africa Group Services Ltd., the largest employer in South Africa's wood 
Identifying Effective Pedagogical Approaches for Online Workplace Training:

A case study of the South African wood products manufacturing sector

Macdonald, Bullen, \& Kozak

products sector, with 32 manufacturing facilities dispersed throughout the country. The company actively encourages and sponsors training and further education for its management-track employees, and was interested in evaluating the potential use of e-learning as a training tool because of the challenge of providing standardized training across multiple sites and in many different countries (Geldenhuys, 2004).

Study participants were selected with the assistance of human resources managers within the company. Candidates were recruited on a voluntary basis, but were required to be working in roles in which the course subject matter would be relevant and beneficial, and to have access to and experience in using a computer. The participants were employed in eight manufacturing facilities located close to the three major urban centres of South Africa: Johannesburg, Cape Town, and Durban.

\section{Data Collection}

In June 2005, approximately three weeks before the course began, pre-course interviews, between one hour and 90 minutes in duration, were conducted with all 20 learners at their workplaces. The objective of the pre-course interviews was to obtain a detailed understanding of the learner group in terms of educational and career histories, personalities, experiences with computers and the Internet, and attitudes and beliefs about teaching and learning. Upon the completion of the elearning course in October 2005, the researcher once again scheduled interviews of a similar length at each learner's workplace. The objective of the exit interviews was to obtain detailed qualitative data on the appropriateness of the various learning activities, assess the perceived level of difficulty of the various activities for learners, identify aspects that were particularly challenging or rewarding, and ascertain how well the various learning activities were perceived by the learners to have helped them to learn the materials. Eighteen learners were interviewed in person, and the remaining two, who had been unable to meet with the researcher due to illness and job-related commitments, were later interviewed by telephone. Six human resources and training managers, who between them were responsible for all eight of the factory locations involved in the study, were also interviewed at this time. WebCT server logs were also monitored during the course, but are not reported here as they did not yield useful data in terms of the effectiveness of pedagogical approaches.

\section{Research Findings}

\section{Learner Profiles}

Participants were fluent English speakers employed in supervisory, management-track, or management roles. Learners had varying degrees of familiarity with the course subject matter, depending on their backgrounds and the types of factories in which they were employed. All participants had adequate computer skills, and most used a computer daily. Some learners were unfamiliar with performing information searches on the Internet and using tools such as chat and discussion forums. None had any prior experience with e-learning, but half had taken at least one correspondence course. Learners who had taken correspondence courses generally liked the flexibility afforded by distance learning, but disliked the lack of interaction and tutor support.

Participants tended to place importance on practical learning outcomes and learning that could be readily applied in personal and professional contexts. A possible reason for this is that people who are attracted to careers in manufacturing favour acquisition of such practical knowledge as 
Identifying Effective Pedagogical Approaches for Online Workplace Training:

A case study of the South African wood products manufacturing sector

Macdonald, Bullen, \& Kozak

they have to solve hands-on problems on the factory floor on a daily basis (Felder \& Silverman, 1988). Learners' responses may also have been influenced by the fact that much of the training that they have done is sponsored by their employer and is vocationally-oriented.

As a group, learners described themselves as more outgoing than reserved, much more experimental than traditional, and more flexible than perfectionist. Learners' epistemological outlook was measured by calculating an average score for each respondent based upon their level of agreement or disagreement with a series of 24 statements on the nature of knowledge and learning. The group leaned more towards constructivist tenets than behaviourist, though not strongly so.

\section{Evaluating the Success of Learning Activities Used}

Upon completion of the course, learners identified specific benefits and drawbacks for each learning activity, but overall saw the mix of activities as appropriate. The inclusion of a variety of differing learning tasks helped to stimulate and maintain the interest of learners and promote engagement. These findings support the work of Tennyson (2002), Mishra (2002), and Sfard (1998), who each advocate instructional design models that borrow from multiple theories of learning to match the most appropriate learning activities to the learning task at hand. Approaching the same concepts through different modalities may also strengthen learners' understanding of the course material, and Spiro, Feltovich, Jacobson, and Coulson (1991) suggest that "revisiting the same material, at different times, in rearranged contexts, for different purposes, and from different conceptual perspectives is essential for attaining the goals of advanced knowledge acquisition” (p.28).

The perceived advantages of each learning task/activity are summarised in Table 2, and further discussion of specific benefits and drawbacks is provided below. 
Identifying Effective Pedagogical Approaches for Online Workplace Training: A case study of the South African wood products manufacturing sector Macdonald, Bullen, \& Kozak

Table 2: Participants' Opinions on Perceived Benefits of Learning Activities

\begin{tabular}{|c|c|}
\hline Learning Activity & Perceived Benefits \\
\hline Quizzes & $\begin{array}{l}\text { - Useful for generating keywords or phrases that } \\
\text { can prompt recall of main concepts } \\
\text { - Require leamers to carefully read course content } \\
\text { - Reinforce what leamers have already read and } \\
\text { aid retention } \\
\text { - Prepare leamers for more complex assignments }\end{array}$ \\
\hline Self-test (optional) exercises & $\begin{array}{l}\text { - Promote deeper understanding of new concepts } \\
\text { - Help relate new concepts to personal experience } \\
\text { or real-world contexts } \\
\text { - Can take on an interactive dimension if leamers } \\
\text { are asked to generate questions for each other to } \\
\text { answer }\end{array}$ \\
\hline $\begin{array}{l}\text { Tasks incorporating external } \\
\text { online resources }\end{array}$ & $\begin{array}{l}\text { - Are interesting and motivating in so much as } \\
\text { extemal resources are authentic } \\
\text { - Expand learners' perspectives on concepts } \\
\text { covered in the course } \\
\text { - Introduce leamers to the availability of a wide } \\
\text { - Vange of readily-acces sible information resources } \\
\text { - Enhance the online research skills of learners }\end{array}$ \\
\hline $\begin{array}{l}\text { Tasks incorporating choice } \\
\text { of topic/area of focus }\end{array}$ & $\begin{array}{l}\text { - Are motivating and interesting as a result of } \\
\text { having a choice on what to write about } \\
\text { - Can focus on topics of personal interest or } \\
\text { relevant to their own work }\end{array}$ \\
\hline Discussions & $\begin{array}{l}\text { - Address issues not covered in course content } \\
\text { - Promote a deeper understanding of issues that are } \\
\text { only mentioned in the course } \\
\text { - Place concepts within the context of learners' } \\
\text { own opinions and experiences, making them } \\
\text { more memorable } \\
\text { - Help learners to understand concepts within a } \\
\text { real-world context } \\
\text { - Alter or reinforce leamers' perspectives by } \\
\text { - Can be used as a means for learners to discuss } \\
\text { questions or problems with each other }\end{array}$ \\
\hline Group work & $\begin{array}{l}\text { - Is interesting and motivating because of the } \\
\text { authentic nature of the activity } \\
\text { - Provides opportunities to share knowledge and } \\
\text { perspectives with colleagues from other factories }\end{array}$ \\
\hline Face-to-face meetings & $\begin{array}{l}\text { - Motivate learners to keep up with course } \\
\text { requirements } \\
\text { - Facilitate the coordination of group work } \\
\text { - Allow for human contact and natural interaction } \\
\text { with peers }\end{array}$ \\
\hline
\end{tabular}


Identifying Effective Pedagogical Approaches for Online Workplace Training:

A case study of the South African wood products manufacturing sector

Macdonald, Bullen, \& Kozak

Most learners found that the short online quizzes were useful in encouraging them to carefully read and review the online course text, and they were also seen to be helpful in building a base of knowledge that could be expanded upon through more complex assignments that required higherorder thinking. Several learners proposed that short quizzes also generated keywords that triggered the recall of the main concepts covered in the course text. This function is similar to that described by Ausubel (1968), who proposes that memory is organised in a hierarchical structure in which anchoring ideas - the strongest and most inclusive concepts within an individual's cognitive structure - provide points for new information to enter and to be assimilated into that structure. If the online course text is structured carefully so that basic concepts are covered first and augmented by more sophisticated material, it is possible to structure quizzes such that questions trigger recall of (and thus, reinforce) the anchoring ideas of the course.

An alternative role for quizzes in online courses is to prepare students for the coming module of content rather than to serve as a review of the content just covered. For example, students could be asked their opinions on various issues related to a topic that will be discussed in an upcoming module. Model answers could provide summaries of the differing perspectives on each of these issues, serving as an introduction to the concepts to be covered in the module. This approach encourages learners to reflect upon their existing knowledge and ideas relevant to the new content to be covered. In doing so, learners are encouraged to relate new information to their relevant existing knowledge and experience (Ausubel, 1960).

The optional self-test questions and exercises in the online text were regarded by learners to be useful in providing ways to relate the concepts being discussed to personal experiences. Participants stated that the most important role of such questions was to make them 'stop and think' about a given concept in greater depth than would be achieved simply by reading course notes. While time-strapped learners skipped over such exercises to focus instead on the assessed tasks, the inclusion of such questions within the course text appears to be a simple and effective means of promoting a deeper understanding of important concepts for those learners with the time and interest to take advantage of them.

Learners saw many benefits in pursuing tasks that incorporated the use of external Web-based sources of information. The authentic nature of third-party websites was noted as a motivating factor, and such sources served to validate, reinforce, and enhance the online course text or provide useful alternative perspectives. Activities involving external Web resources also enhanced learners' skills in conducting Internet-based research, and opened learners' eyes to the wealth of information available to them online. The perceived drawback of such activities was the greater time requirement, as learners typically reported that finding and evaluating information from online sources was much more time-consuming than writing an assignment based on information in the online course text. The need for extra time was exacerbated by the slow download speeds of many South African websites and company networks. For this reason, it may be prudent for course designers, in certain contexts, to restrict the number of learning tasks in any one course that require learners to access external websites. A possible time-saving solution is to post excerpts or copies of documents from external sites on the course Web server and link them to the course text. While this would be more convenient for some learners, it does reduce the perceived authenticity of the information source, and prevents learners from developing Internetbased research skills. This trade-off is one that must be carefully considered by the instructional designer.

Online asynchronous discussions were seen as a stimulating way of allowing learners to consider a range of perspectives beyond that of the course author. The discussions provided a means for 
Identifying Effective Pedagogical Approaches for Online Workplace Training:

A case study of the South African wood products manufacturing sector

Macdonald, Bullen, \& Kozak

topics introduced in the course text to be explored in greater depth, and for new issues to be raised and debated. Learners saw significant value in having to frame the concepts raised in the course within the context of their own experience and opinions, and stated that doing so made those concepts more memorable. Reading the differing perspectives of peers was also regarded as worthwhile, as it reinforced or altered learners' own views and often augmented their knowledge. Lastly, the discussion forum was seen as a medium through which learners could help each other with any problems that they were experiencing during the course.

The group assignment was found by most learners to be a useful and appropriate learning activity, and the authentic nature and interactive dimension of the task drew positive comments similar to those made about the discussion forum and use of external Web-based resources. Many learners, however, were discouraged by the complexities involved in communicating with team members who were based in other locations. Learners who were already very busy now had to deal with the differing working hours of group members at other factories. This could be mitigated by creating groups composed of learners based in the same location, so that face-to-face group meetings could occur. Organizing learners into groups earlier in the course to allow more time for preparation may also be prudent.

Most of the study participants suggested that the course could be improved by including a faceto-face meeting component. In addition to simplifying the logistics of group work, holding meetings of course participants in each region may increase motivation to complete assessed tasks on time, and would create the human interaction that is lacking in pure e-learning courses. For a course of three to four months, one meeting per month may be sufficient to yield such benefits. Dagada and Jakovljevic (2004) found that South African facilitators of e-learning courses favoured this kind of blended learning approach, and South African researchers, van der Westhuizen and Krige (2003), also found that participants involved in e-learning expressed a strong desire for face-to-face interaction.

These findings suggest that e-learning can be made more effective when combined with other methods of educational delivery, and this concept is supported by writers such as Gray (2006) who proposes an instructional design model that links instructional delivery methods with the various stages in the learning process and the educational goals that must be met at each stage.

Although there was a general consensus that a mix of learning activities was beneficial, learners did not have a unanimous view on how the course should be structured. The structure used in this study, in which a familiar behavioural approach at the beginning transitions to a constructivist model in the later stages, may be appropriate where learners are taking an e-learning course for the first time. Many learners, however, suggested that short-answer quizzes should be included in all of the modules in order to prepare learners for more open-ended assignments. The choice of learning activities employed should also be dependent on the content and desired learning outcomes for each module.

\section{Conclusions and Recommendations}

This study found that learning activities designed according to the constructivist philosophy are appropriate for online training of adult learners in the South African wood products (furniture) industry. Although such activities were seen to be more time-consuming than short quizzes or assignments based on course notes only, they were believed to promote deeper understanding and better retention of new concepts. 
Identifying Effective Pedagogical Approaches for Online Workplace Training:

A case study of the South African wood products manufacturing sector

Macdonald, Bullen, \& Kozak

The learners who participated in this study tended to place greater importance on practical outcomes than on purely theoretical knowledge. To achieve practical outcomes, it is necessary to apply new knowledge in context, and a dominant belief among constructivist educators is that learning activities must reflect the complex problems that individuals are required to deal with in real life (Driscoll, 2000). The course involved many opportunities for learners to relate concepts introduced in the course to the context of real-world industry issues and to their own personal experiences and those of their peers. This may have been one of the key reasons why such activities were highly valued by the group. Learners regarded quizzes and summary-type assignments as helpful when trying to commit new facts to memory, but constructivist activities were seen to be essential for turning those facts into actionable knowledge. This concept is supported by Brown, Collins, and Duguid (1989), who propose that, if learning is not done within the context of meaningful activity, knowledge will remain untapped even when relevant problems present themselves.

Constructivist activities should not be employed to the exclusion of other approaches, however. Each of the learning activities employed in the course yielded specific benefits, and instructional designers should exploit these to create learning environments that stimulate and engage workplace learners. Based on this case study of South African workplace learners, the following recommendations (with their implications for pedagogy and instructional design) are proposed as a summary of the findings:

1. Workplace e-learning courses should include a mix of tasks and activities that encourage learners to approach new concepts in a variety of ways.

2. Constructivist activities should be used to enable learners to link new knowledge to realworld contexts. For situations in which learners are not familiar with the constructivist approach, the course should begin with behaviourist/ didactic activities in the early stages and move in incremental steps toward constructivist methods.

3. Authentic tasks and research based on external Web research should be included, but instructional designers should carefully consider the time demands on learners when planning overall workloads.

4. Ample opportunities for interaction between students should be created.

5. Face-to-face meetings should be included to minimise isolation and procrastination and to facilitate group work.

This study has considered the specific case of learners involved in manufacturing roles within the South African wood products industry. As mentioned above, the learners' enthusiasm for constructivist pedagogical approaches may be partially attributable to the practical nature of their jobs and their desire to quickly implement newly-gained knowledge to improve workplace performance. Further research comparing workplace learners in a variety of sectors would be useful to ascertain the relative important of such factors in the success of constructivist teaching and learning methods.

\section{Limitations of the Study}

This study is limited by a number of factors. The qualitative approach used is an appropriate means of collecting detailed information on learner attitudes and experiences, but the small 
Identifying Effective Pedagogical Approaches for Online Workplace Training:

A case study of the South African wood products manufacturing sector

Macdonald, Bullen, \& Kozak

sample size means that the results are not statistically meaningful. For this reason, judgments about the usefulness and credibility of the results must be left to the researcher and the reader (Eisner, 1991).

In qualitative research, sampling errors can arise from insufficient breadth in sampling, distortions due to changes over time, or lack of depth in data collection at each site (Patton, 1990). To address the risk of insufficient breadth in sampling, participants from a number of locations, demographic profiles, and job roles were asked to participate in the study. Learning technologies and information and communication technologies change rapidly and, while this study attempted to focus on pedagogical and organisational factors rather than technology itself, it was inherently influenced by such changes. The study attempted to ensure that robust data was collected through the detailed in-depth interviews conducted with each participant.

A limitation of the pilot e-learning course itself is that it was not accredited by the Ministry of Education in South Africa, since it was not feasible to undertake a lengthy application process for the purpose of a one-time, three-month pilot course. This factor may have resulted in lower levels of learner motivation than if the course had been accredited. Lastly, the "pilot program" nature of the course may also have tempted some learners to take the course less seriously than would have been the case if the course had been a training program offered regularly by the company or another external training provider.

\section{Acknowledgements}

The authors would like to thank all of the adult learners who participated in the study, Mr. Craig Stewart at Steinhoff Africa Group Services, and Professor David Cohen, author of the course used in the study. We would also like to acknowledge the funding support of Canadian International Development Agency.

\section{Foot Notes}

1. Although the official Statistics South Africa unemployment figure for the same year was $27.8 \%$, the expanded definition, which includes unemployed people who have given up looking for work, is more commonly cited.

2. To ensure impartiality, grading of participants' assessed work was done by other faculty members at the University of British Columbia and the University of Stellenbosch.

\section{References}

Akerlind, G., \& Trevitt, C. (1995). Enhancing Learning Through Technology: When students resist the change. Proceedings of ASCILITE 95 - Learning with Technology, 3-7 December, Melbourne, Australia.

Ausubel, D. (1960). The use of advance organizers in the learning and retention of meaningful verbal material. Journal of Educational Psychology, 51, 267-272.

Ausubel, D. (1968). Educational Psychology: A cognitive view. New York: Holt, Rinehart \& Winston. 
Identifying Effective Pedagogical Approaches for Online Workplace Training: A case study of the South African wood products manufacturing sector

Macdonald, Bullen, \& Kozak

Brown, J., Collins, A., \& Duguid, P. (1989). Situated cognition and the culture of learning. Educational Researcher, 18(1), 32-42.

Cronbach, L. J. (1975). Beyond the two disciplines of scientific psychology. American Psychologist, 30(2), 116-127.

Dagada, R., \& Jakovljevic, M. (2004). Where have all the trainers gone? E-learning strategies and tools in the corporate training environment. Proceedings of the 2004 annual research conference of the South African Institute of Computer Scientists and Information Technologists on IT Research in Developing Countries. Stellenbosch: South Africa.

Driscoll, M. P. (2000). Psychology of learning for instruction. Needham Heights, MA.: Allyn \& Bacon.

Eisner, E. W. (1991). The Enlightened Eye: Qualitative inquiry and the enhancement of educational practice. New York: Macmillan.

FIETA (2006).Website of Forest Industries Education \& Training Authority (FIETA). Retrieved April 9, 2006 from: http://www.fieta.org.za

Felder, R., \& Silverman, L. (1988). Learning and teaching styles in engineering education. Engineering Education, 78(7), 674-681.

Geldenhuys, J. (2004). Personal telephone conversation, September, 6, 2004.

Gray, C. (2006). Blended Learning: Why everything old is new again - but better. Learning Circuits. Retrieved May 15, 2007 from: http://www.learningcircuits.org/2006/March/gray.htm

Längin, D., Lewark, S. \& Ackerman , P. (2004). Internet-based learning in higher forestry education. UNASYLVA: Forestry Journal of the FAO, 216, 39-44. Retrieved May 8, 2006 from: http://www.fao.org/forestry/site/unasylva/en

Mishra, S. (2002). A design framework for online learning environments. British Journal of Educational Technology, 33(4), 493-496.

Patton, M. Q. (1990). Qualitative evaluation and research methods (2nd ed.). Newbury Park, CA: Sage.

Sfard A. (1998). On two metaphors for learning and the danger of choosing just one. Educational Researcher, 27(2), 4-13.

Spiro, R. J., Feltovich, P. J., Jacobson, M. J., \& Coulson, R. L., (1991). Cognitive Flexibility, Constructivism, and Hypertext: Random access instruction for advanced knowledge acquisition in ill-structured domains. Educational Technology, 31(5), 24-33.

Streak, J., \& van der Westhuizen, C. (2004). Fitting the Pieces Together: A composite view of the government's strategy to ASSIST THE UNEMPLOYED in South Africa 1994 - 2004. 
Identifying Effective Pedagogical Approaches for Online Workplace Training: A case study of the South African wood products manufacturing sector

Macdonald, Bullen, \& Kozak

Institute for Democracy in South Africa, October 12, 2004. Retrieved April 9, 2006 from: http://www.idasa.org.za.

Tennyson, R. D. (2002). Linking learning theories to instructional design. Educational Technology, 42(6), 7-12.

van der Westhuizen, D., \& Krige, H. (2003). Ending the divide between online learning and classroom instruction using a blended learning approach. In P. Kommers \& G. Richards (Eds.), Proceedings of World Conference on Educational Multimedia, Hypermedia and Telecommunications 2003 (p. 2527-2528). Chesapeake, VA: AACE. Retrieved February 28, 2006 from: http://www.editlib.org

World Bank (2000). The digital divide and the World Bank Group. Washington, D.C.: World Bank.

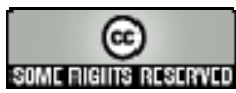

